\title{
La fotografía como creadora de la imagen de un destino turístico cultural sustentable en el Parque Nacional Mochima, Estado Sucre
}

\section{Creative photography as an image of sustainable cultural tourism \\ destination in the National Park Mochima, State Sucre}

\author{
Enviado em:13/11/2017 \\ Aceito em: 05/01/2018 \\ Milagros Elena Rodríguez ${ }^{1}$
}

\section{Resumen:}

En este ensayo se analiza el modo en que la fotografía crea y difunde imágenes y símbolos turísticos culturales en este caso del Parque Nacional Mochima, en el Estado Sucre, Venezuela y sus implicaciones en la construcción e interpretación de la imagen de su destino turístico en el contexto histórico, social y cultural actual. La imagen turística representada a través de la fotografía constituye el primer encuentro subjetivo, hermoso entre el destino turístico cultural del Parque Nacional Mochima y cobrar un papel muy importante para dar a conocer, preservar y disfrutar el patrimonio cultural y turístico de nuestro hermoso patrimonio natural. Se interrelacionan tres elementos, patrimonio, turismo y cultura que son difíciles de nivelar, ya que mientras que el turismo se ha considerado históricamente como una actividad preponderantemente económica como ha venido ocurriendo en dicho lugar, el patrimonio es una riqueza no renovable que no puede considerarse un producto tradicional de consumo. Se consideran aspectos que conlleven a una sustentabilidad ecológica; esto es la base física del proceso de desarrollo que conlleva a la conservación y uso racional de los recursos naturales incorporados a la actividad productiva en el Parque.

Palabras Clave: Parque Nacional Mochima, turismo cultural sustentable, fotografía.

\section{Abstract:}

1 Postdoctora en Ciencias de la Educación, Doctora en Innovaciones Educativas, Magister Scientiarum en Matemáticas, Licenciada en Matemática, Universidad de Oriente. 
In this essay how photography creates analyzes and disseminates images and cultural tourist symbols in this case Mochima National Park in the State of Sucre, Venezuela and its implications for the construction and interpretation of the image of the tourist destination in the current historical, social and cultural context. The tourism image represented through photography is the first subjective, beautiful encounter between cultural tourist destination in the Mochima National Park and charge a very important role to present, preserve and enjoy cultural and touristic heritage of our beautiful natural heritage. three elements, heritage, tourism and culture that are difficult to level interrelate, and that while tourism has historically considered a preponderantly economic activity as has been happening in that place, heritage is a non-renewable wealth that can not be considered a traditional consumer product. They are considered aspects that lead to ecological sustainability; this is the physical basis of the development process leading to the conservation and wise use of natural resources incorporated into the productive activity in the park.

Keywords: Mochima National Park, sustainable cultural tourism, photography.

La vista del paisaje, desde la vía de la carretera de la Ciudad de Puerto la Cruz a Cumaná, Venezuela, es un ensueño plasmado tantas veces desde el lente de la cámara de la autora de éste ensayo que en oportunidades ha dejado ver en muchas páginas web, blog, redes sociales, entre otros medios, enalteciendo nuestro patrimonio natural; se trata en este caso del Parque Nacional Mochima, decretado en 1973 con tal, patrimonio natural por excelencia. 
Figura 1. La vista del Parque Nacional Mochima

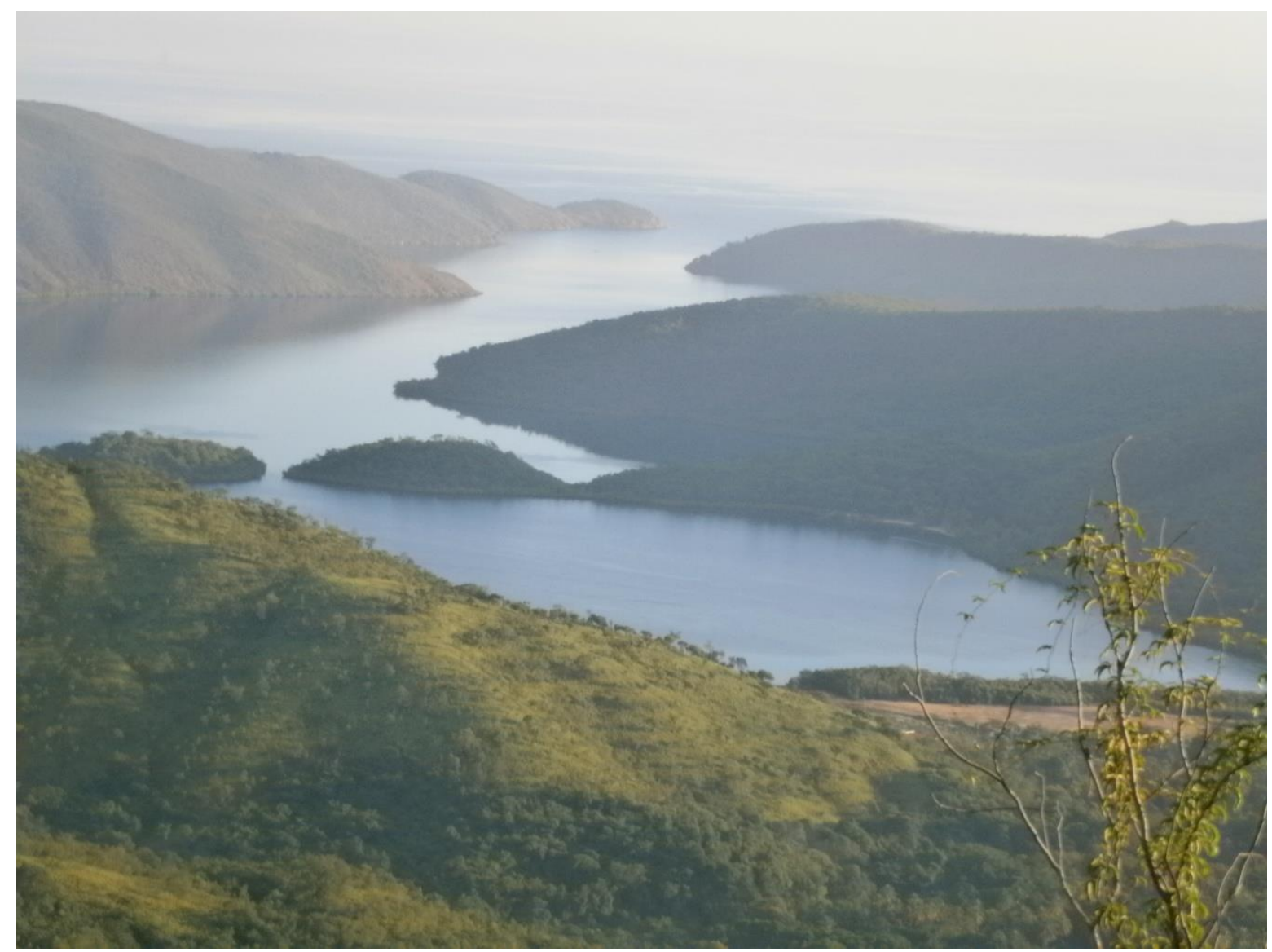

Fuente: Propiedad de la autora del ensayo

Se sabe que el Parque Nacional Mochima es uno de los sitios turísticos por excelencia de visita al Estado Sucre, donde se practican deportes de playas de diversos tipos, el submarinismo y otras actividades acuáticas y se realizan paseos en lanchas por todo el parque acompañados de charlas sobre la biodiversidad natural que se puede conseguir incluyendo los delfines y la diversidad en sus aguas trasparentes que deja ver, por ello que la autora como lo afirma Sontag (2006, p.15) "coleccionar fotografías es coleccionar el mundo", y es la manera de mostrar tan mágico lugar, he aquí una muestra. 
Figura 2. Fotografía de los asteroideos o estrellas de mar

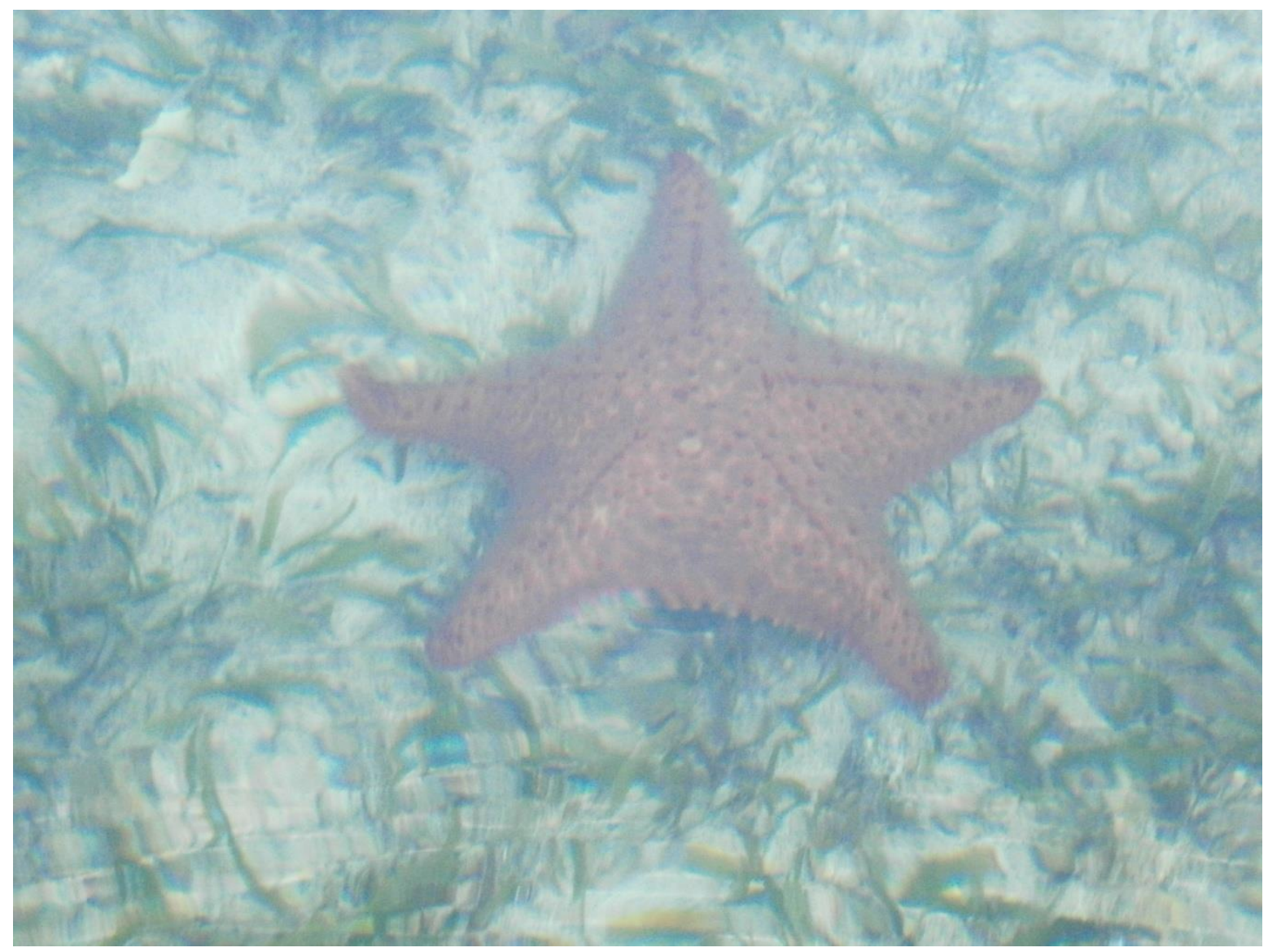

Fuente: Propiedad de la autora del ensayo

EI Parque nacional Mochima debe ser mostrado desde la fotografías y transmitirse de manera clara y directa para que siembre el deseo de viajar, y debe actualizarse y reconvertirse continuamente, el color de sus paisajes, la luz tenue en cada imagen deja ver la belleza imaginada en las mentes de cada uno. 
Figura 3. Los rayos del sol en medio de sus formaciones de rocas

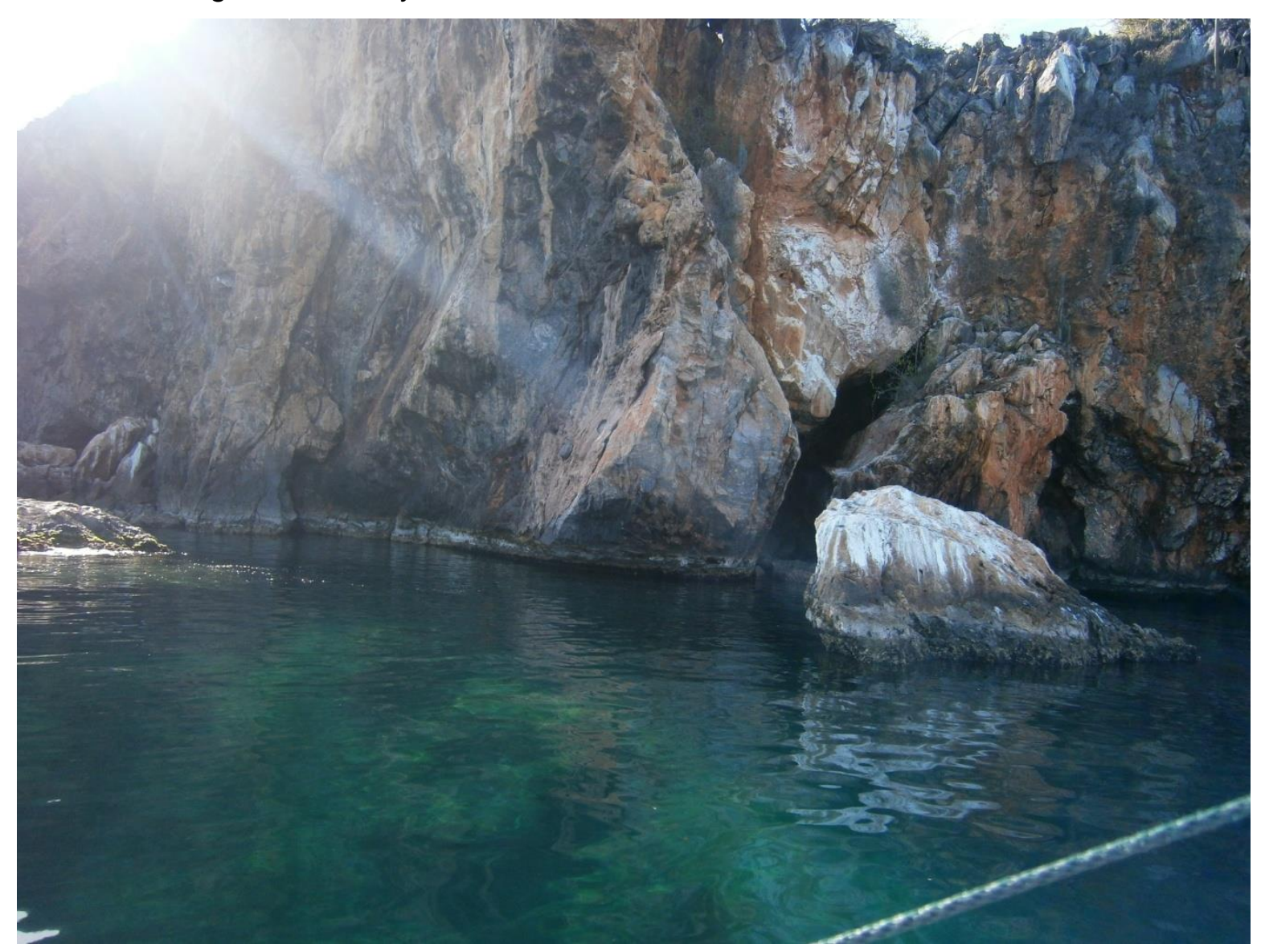

Fuente: Propiedad de la autora del ensayo 
Figura 4. El reflejo de sus manglares en el mar

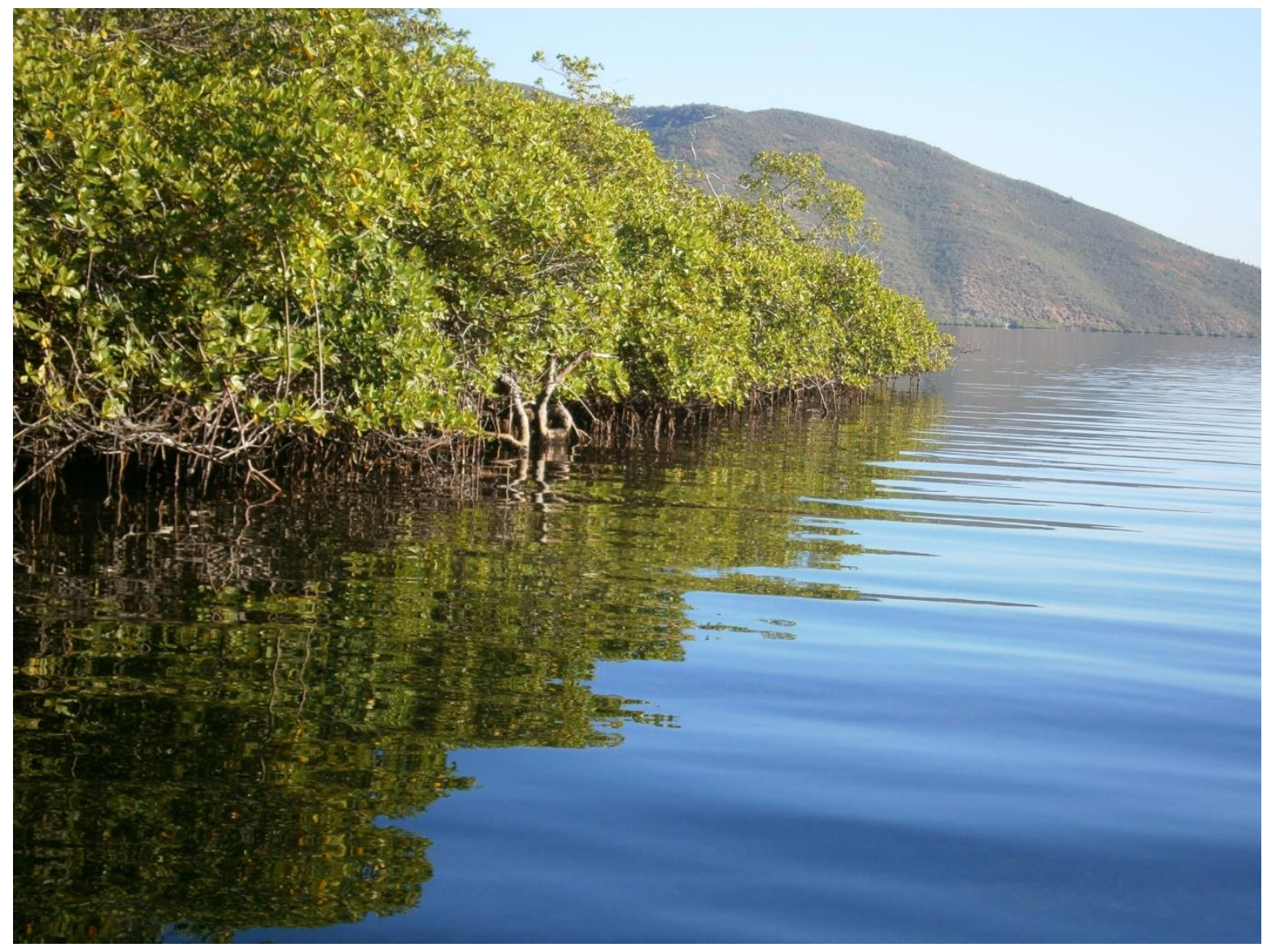

Fuente: Propiedad de la autora del ensayo

Se analiza el modo en que la fotografía crea y difunde imágenes y símbolos turísticos culturales en este caso del Parque Nacional Mochima, en el Estado Sucre, y sus implicaciones en la construcción e interpretación de la imagen de su destino turístico sustentable en el contexto histórico, social y cultural actual. Es necesaria la búsqueda de estrategias encaminadas a fomentar el desarrollo del turismo cultural, no solamente como motor económico del Parque Nacional Mochima, sino también como preservador de los valores y del patrimonio natural, desde una perspectiva que garantice el respeto y la conservación del mismoa través de un mayor conocimiento entre los turistas, y de intercambios interculturales fructíferos que contribuyan al desarrollo económico, social y 
cultural de dicho lugar. Se trata de la sustentabilidad ecología necesaria y pertinente. Las generaciones futuras deben disfrutar de ese lugar cuidado, preservado en su flora, fauna, ambiente natural de tal manera todo debe estar realizado de manera responsable con planes de cuidado y la no explotación y contaminación del ambiente.

Fotografiar es apropiarse de lo fotografiado. Significa, según Sontag (2006) establecer con el mundo una relación determinada que parece conocimiento, y por lo tanto poder. Sontag (2006, p.15) afirma que "al enseñarnos un nuevo código visual, las fotografías alteran y amplían nuestras nociones de lo que merece la pena mirar y de lo que tenemos derecho a observar. Son una gramática y, sobre todo, una ética de la visión". La autora se apropia del paisaje mostrando un turismo cultural del Parque Nacional Mochima que tiene su origen la cultura, y según Morére y Perelló (2013, p.19) el "consumo vertebra, de hecho, todas las parcelas de nuestra vida cotidiana bajo múltiples formas (patrimonio, lengua, hábitos, creaciones artísticas, tradiciones, gastronomía). (...) adquiere como nunca una dimensión cultural a través de las distintas experiencias que los viajeros viven a lo largo de la estancia".

Se trata de un turismo cultural que converja desde luego en un mercado consumo, como ocurre en la Población de Mochima donde ellos organizados en Posadas, paseos en lanchas, servicios de restaurantes y comidas típicas allí en la playa de su elección también se tomen en cuenta el valor del turismo cultural y su misión la preservación del patrimonio natural. Se deberán crear medidas para que el sitio como patrimonio no renovable sea preservado, su fauna no se destruida y la inmensa cantidad de personas que anualmente lo visitan tomen conciencia del valor natural que allí se encuentra. La inmensa belleza que se allí se contempla la autora allí la plasma en fotos de contraluz maravillosas, con un toque particular de amor por el paisaje. Como pueden observar. El ecosistema del parque es saludable si puede proporcionarle a las personas y a los organismos que lo habitan bienes y servicios que no impacten negativamente en el ambiente. 
Figura 5. Lo transparente de sus aguas, Playa Blanca

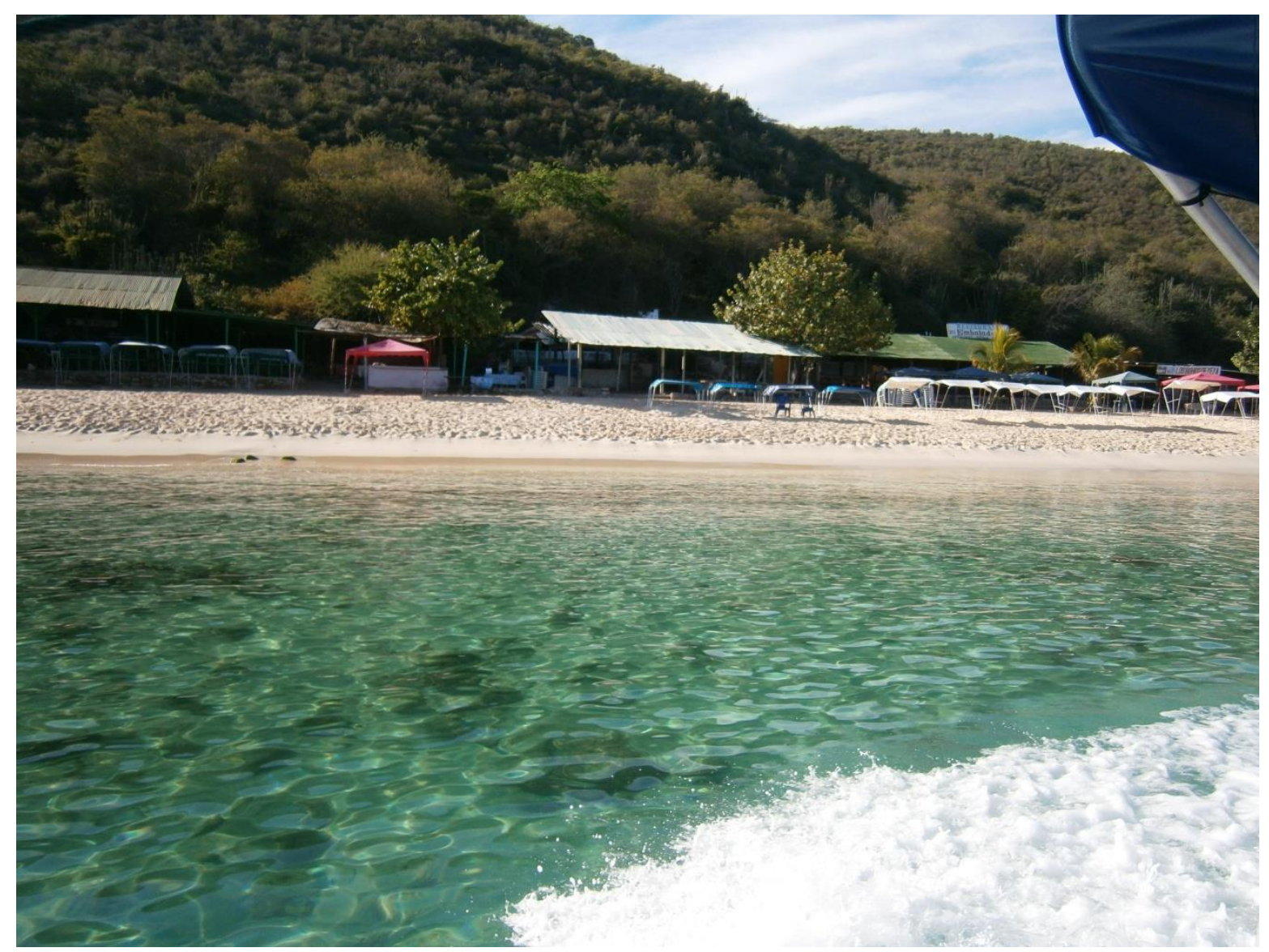

Fuente: Propiedad de la autora del ensayo 
Figura 6. Sus formaciones rocosas en formas de montañas

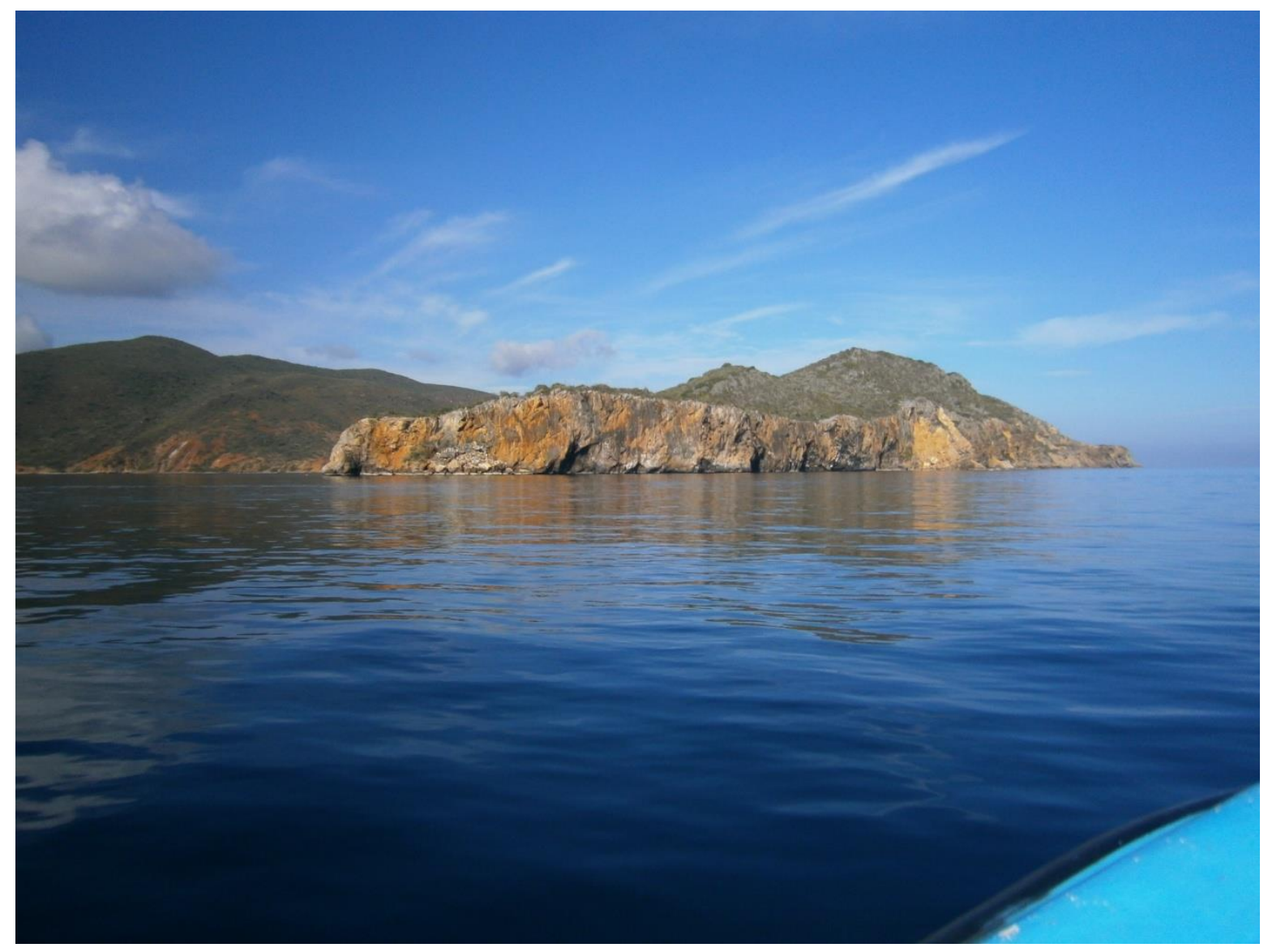

Fuente: Propiedad de la autora del ensayo

No hay duda de que la fotografía establece según Bourdieu (2006, p.66) un "poder simbólico es, en efecto, ese poder invisible que no puede ejercerse sino con la complicidad de los que no quieren saber que lo sufren o incluso que lo ejercen". Es la forma, al menos una de las más efectivas, de llegar a la gente. La práctica fotográfica del turismo es una práctica significante que objetiva en la película un conjuntode discursos y también se compone enparte constituyente de la cultura, configurándose como uno de los elementos componentesde las relaciones sociales. En la zona del Parque de Mochima converge la religión con imágenes alusivas de Vírgenes y Santos, incrustados en las formaciones rocosas, que llama mucho la atención de los creyentes en ello; aun cuando para la autora es DIOS el único y verdadero dueño de este mundo. Es una mágica poética de especial valor. 
Figura 7. Exposiciones de Imágenes religiosas.

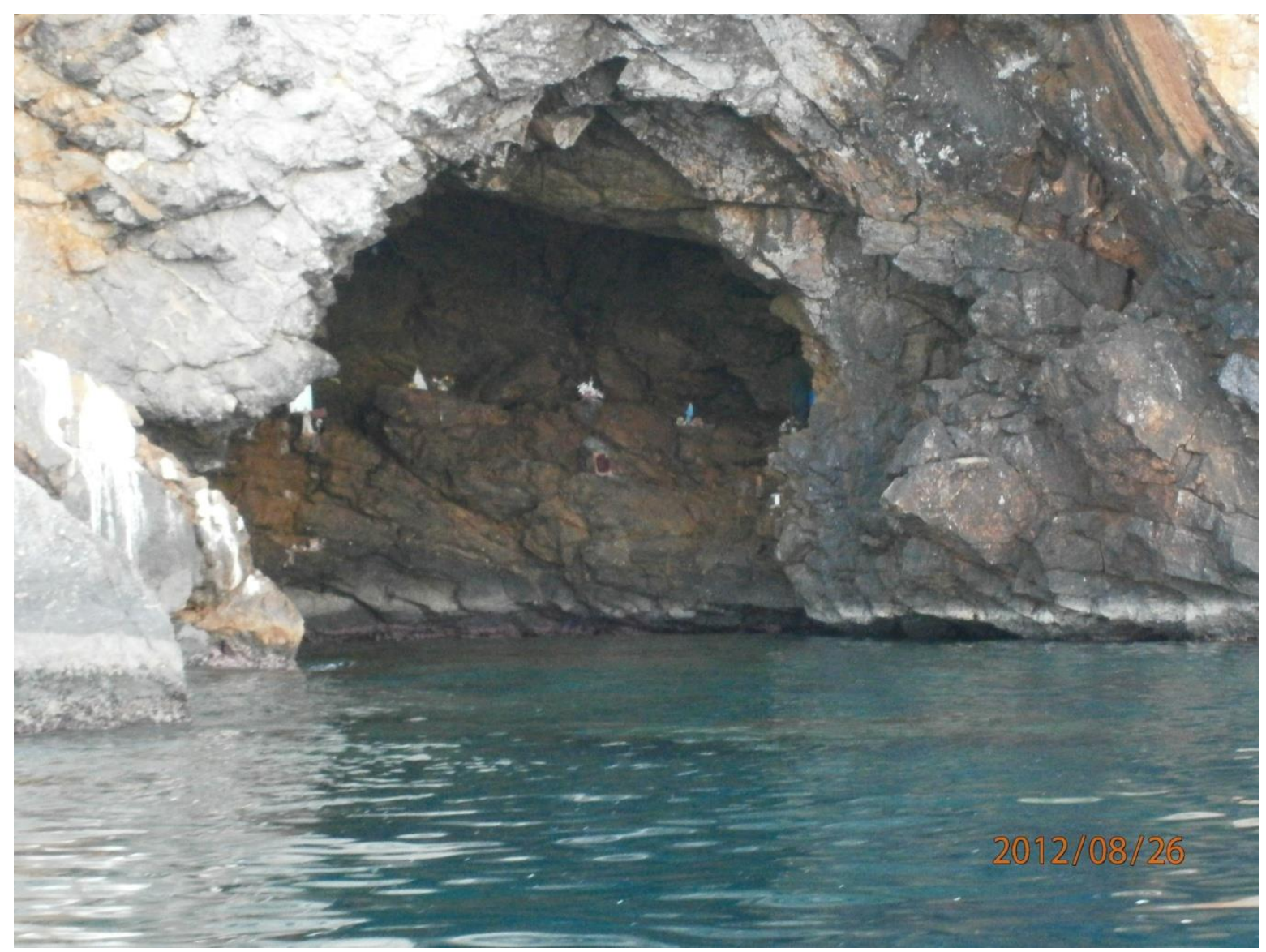

Fuente: Propiedad de la autora del ensayo 
Figura 8. Exposiciones de Imágenes religiosas

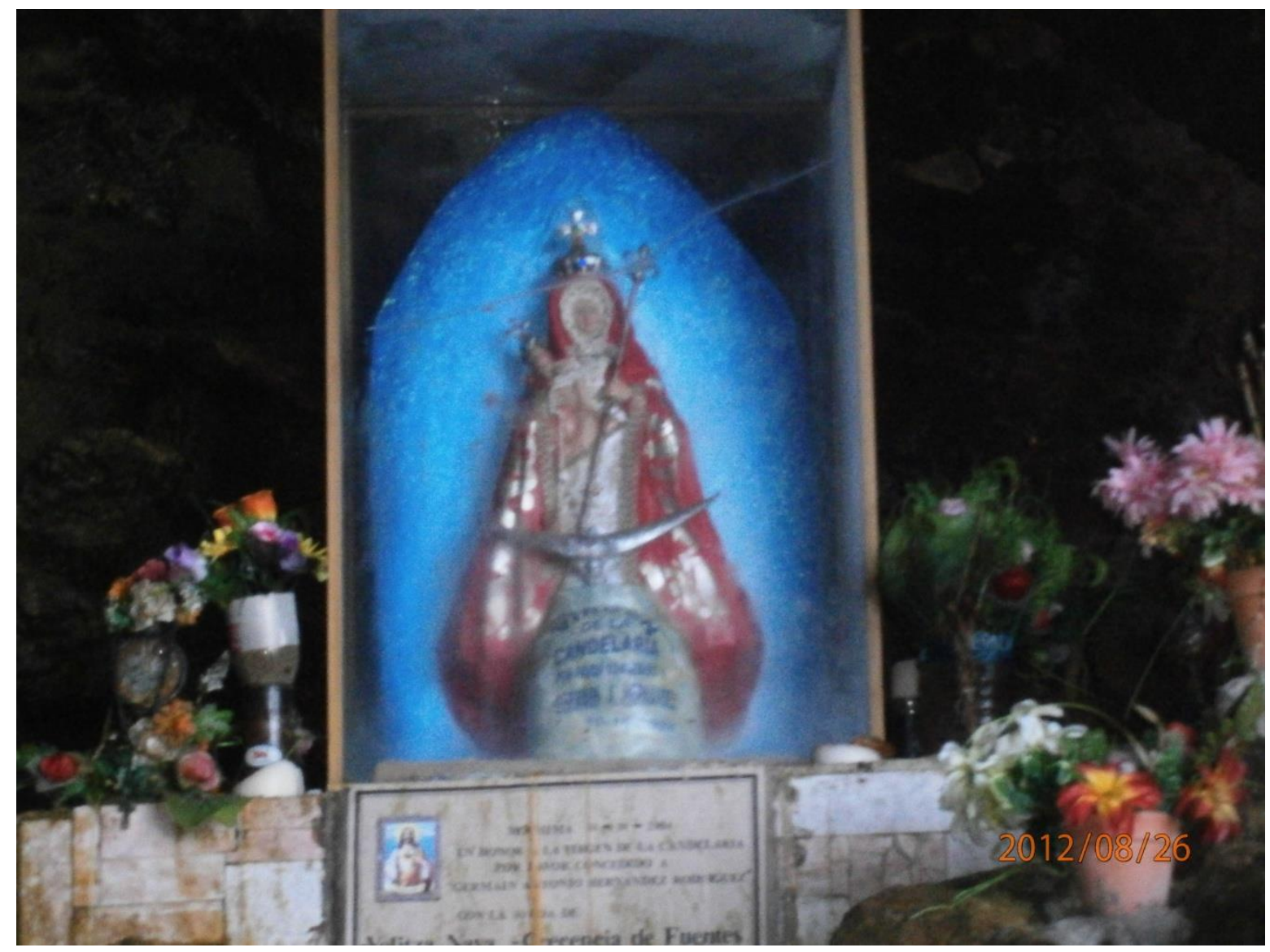

Fuente: Propiedad de la autora del ensayo

La imagen turística representada a través de la fotografía, experimentada personalmente con el lente de mi cámara durante ya más de 28 años, desde paseos y exploraciones, constituye el primer encuentro subjetivo, hermoso entre el destino turístico cultural del Parque Nacional Mochima que he logrado disfrutar junto a mi familia y acompañantes de muchas partes de Venezuela. Desde allí y ahora en mi responsabilidad y trinchera ética de colaborar en la preservación del patrimonio natural venezolano, ejerzo acciones con un papel muy importante para dar a conocer, preservar y disfrutar el patrimonio cultural y turístico de nuestro hermoso patrimonio natural. Desde la autora, y lo reafirma Vásquez (2011, p.305) "el fotógrafo, al participar honesta y visceralmente del mundo sobre el 


\section{memório}

que reflexiona, lo hace movido casi siempre por la empatía y el enamoramiento que lo acerca a las circunstancias escudriñadas con su aliento, con su mirada y sus afectos".

La página web, personal, titulada Mi Bella Venezuela, donde pueden disfrutar fotografías de paisajes venezolanos, con especial atención al Estado Sucre de donde emergen imágenes de sentires especiales: https://plus.google.com/+MIBELLAVENEZUELA/ aquí se publican imágenes del Parque Nacional Mochima como:

Figura 9. Formaciones en el Parque Nacional Mochima

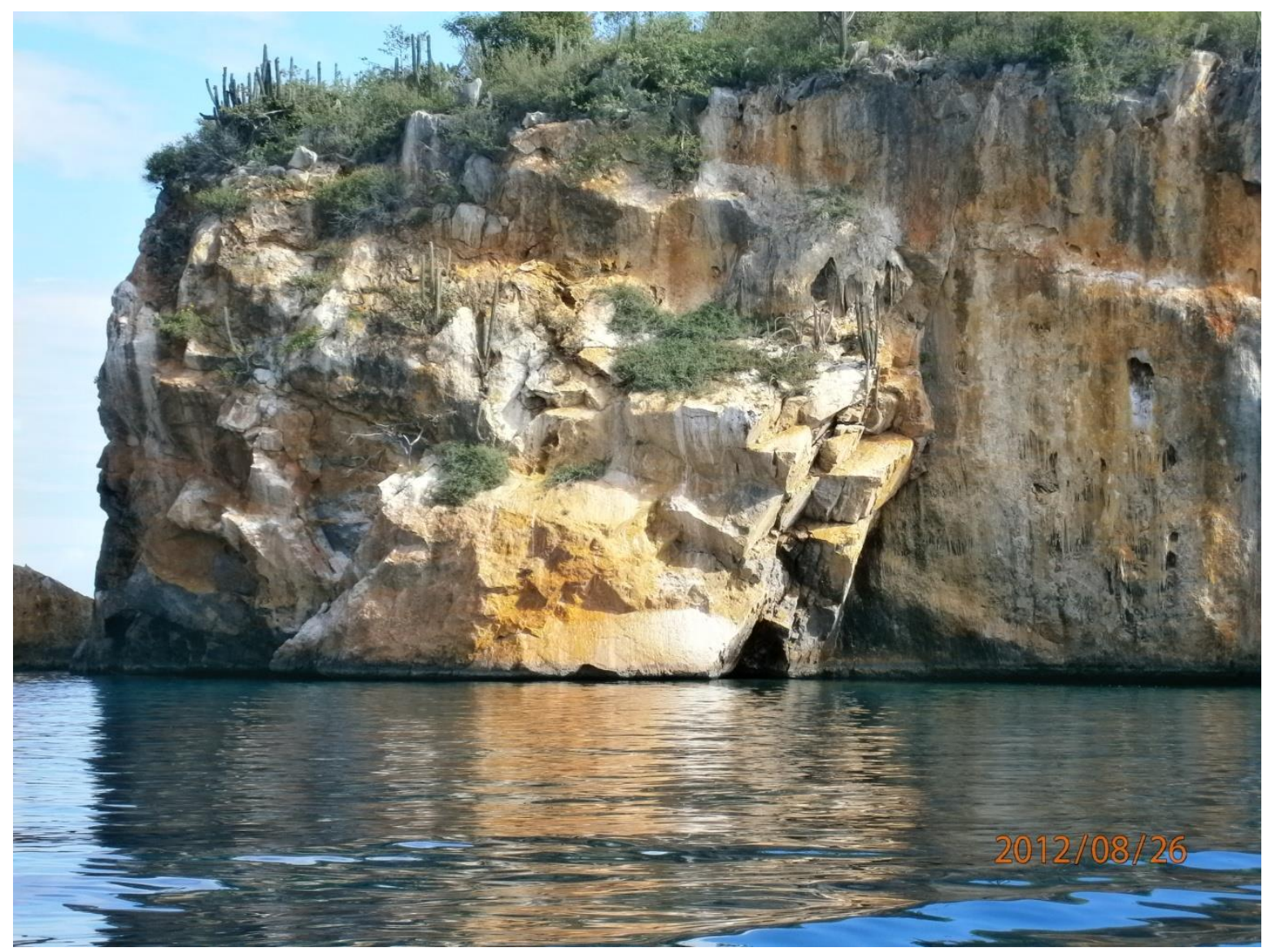

Fuente: Propiedad de la autora del ensayo

La fotografía como creadora de la imagen de un destino turístico cultural en el patrimonio natural Parque Nacional Mochima, Estado Sucre permite desde dicho turismo en su parte cultural según la UNESCO, la que redactaría la primera definición de Turismo 
Cultural en 1976 plasmada en la Carta de Turismo Cultural, "ejerce un efecto realmente positivo sobre éstos en tanto en cuanto contribuye a su mantenimiento y protección. Esta forma de turismo justifica, de hecho, los esfuerzos que tal mantenimiento y protección exigen de la comunidad humana, debido a los beneficios socio-culturales y económicos que comporta para toda la población implicada".

En el Parque Nacional Mochima existen consumidores turísticos de casi todos los países, que según Niemczyk (2013) este representa en la actualidad uno de los mayores segmentos del mercado turístico global. Es un lugar apetecible para vivir diferentes emociones, en el contemplan aspectos culturales y patrimoniales de orden natural como la fauna marina, la vegetación, entre otras junto al misticismo, la comida, el deporte. Que desde luego en la fotografía consigue su aliado para captar nuevos visitantes y de alguna manera contribuir a una colección del acervo fotográfico patrimonial que propenda la preservación de tan valioso regalo natural de singular belleza.

Desde la fotografía se pretende contribuir al turismo cultural que también seaun turismo sustentable porque presta mayor atención a la vulnerabilidad del medio ambiente del parque nacional Mochima, es decir, a los impactos negativos ocasionados por el turismo y la urgencia de considerar en el desarrollo turístico la preservación de los recursos naturales y culturales en todo momento. Es desde la contemplación de la belleza en imágenes la toma de conciencia de un comportamiento ético consciente y pleno a la hora de visitar tan mágico lugar; desde luego posibilitando su conservación y preservación, promoviendo una mejora significativa de los entornos de existencia de la población de Mochima, y buscando el bienestar de los turistas; siempre con la máxima de que el ecosistema no debe afectarse ante tanta belleza del patrimonio natural. Mochima, tierra de muchas aguas, paraíso de mis amores seguiré con mi lente hasta plasmar en el tu color e inmensidad, sonrisa infinita de paz.

\section{Referencias}

BOURDIEU, Pierre. Sobre el poder simbólico, en Intelectuales, política y poder, Buenos Aires, Editorial Universitaria de Buenos Aires, 65-73, 2006. 
ICOMOS. Carta de Turismo Cultural. Bélgica: Comité Científico Internacional de Itinerarios Culturales (CIIC) del ICOMOS, 1976.

MORÉRE, Nuria y PERELLÓ, Salvador. Turismo cultural patrimonio, museos y empleabilidad. Madrid, Fundación EOI, 2013

NIEMCZYK, Andrzej. Cultural tourists: "An attempt to classify them”, Tourism Management Perspectives, 5, 24-30, 2013

SONTAG, Susan. Sobre la fotografía. México, Alfaguara, 2006.

VÁSQUEZ, Alejandro. El ensayo fotográfico, otra manera de narrar. QUÓRUM ACADÉMICO, Vol. 8, № 16, 301 - 314,2011. 